\title{
A Drought Adaptation Management System for Groundwater Resources Based on Combined Drought Index and Vulnerability Analysis
}

\author{
Haitham Al Adaileh ${ }^{1}$ (D) Mohammed Al Qinna ${ }^{2} \cdot$ Károly Barta $^{3} \cdot$ Emad Al-Karablieh $^{4} \cdot$ János Rakonczai $^{3}$. \\ Adel Alobeiaat ${ }^{5}$
}

Received: 19 July 2019 / Accepted: 12 September 2019 / Published online: 4 October 2019

(c) The Author(s) 2019

\begin{abstract}
Water scarcity is one of the largest global risks in terms of potential impact over the next decade as it affects every continent is manifested by partial or no satisfaction of expressed demand, economic competition for water quantity or quality, disputes between users, irreversible depletion of groundwater, and negative impacts on the environment. Jordanian water crises are exacerbating all of the time due to increased water demands derived from high population growth, sudden fluxes of refugees, economic development, and increased frequency of drought events. These forces stress the urgent need to develop drought adaptation planning based on vulnerability mapping correlated to prolonged weather events. The objective of this research is thus to generate a drought vulnerability map with an emphasis on the severity and probability of drought occurrence, and to propose adaption measures based on groundwater sector impact chain analysis by incorporating numerical scorings for exposure, sensitivity, and adaptive capacities at groundwater basin and Jordanian district levels. Drought impacts on groundwater basins were investigated based on measurements of severity and probability of drought occurrence, and drought exposure over the whole country computed by means of a combined drought index (CDI) that included the precipitation drought index, temperature drought index, and vegetation drought index from 1980 to 2017. Results indicated that drought in Jordan is characterised by a temporal and spatial variability regarding probability and severity. The most prolonged drought events range from mild to moderate, with long periods of exposure that may extend for up to 13 consecutive years. Due to high groundwater basin sensitivity and low adaptive capacity, the groundwater systems in Jordan are fragile and highly vulnerable to drought impacts, being subject to either reduction in quantity and/or deterioration in quality over time. The most vulnerable groundwater basins are the Azraq and Dead Sea regions, while Disi and Yarmouk are also highly vulnerable groundwater basins based on the weak enforcement of transboundary agreements. The proposed drought risk management system based on this research includes proactive and contingency plans enabled by policies and legal frameworks at the national level to ensure sustainable water resilience and governance.
\end{abstract}

Keywords Combined drought index $\cdot$ Vulnerability map $\cdot$ Drought impacts · Adaptation measures $\cdot$ Jordan

Haitham Al Adaileh

hadaileh@geo.u-szeged.hu; hadaileh@hotmail.com

Mohammed Al Qinna

qinna@hu.edu.jo

Károly Barta

barta@geo.u-szeged.hu

Emad Al-Karablieh

karablie@ju.edu.jo

János Rakonczai

J.Rakonczai@geo.u-szeged.hu

Adel Alobeiaat

Adel_Alobeiaat@mwi.gov.jo
1 Doctoral School of Environmental Science, The University of Szeged, Szeged, Hungary

2 Department of Land Management and Environment, Faculty of Natural Resources and Environment, Hashemite University, Zarqa, Jordan

3 Department of Physical Geography and Geo-informatics, The University of Szeged, Szeged, Hungary

4 Department of Agricultural Economics and Agribusiness Management, School of Agriculture, The University of Jordan, Amman, Jordan

5 Ministry of Water and Irrigation, Amman, Jordan 


\section{Introduction}

Jordan's water scarcity is ranked the second worst in the world, and it is a significant well-documented problem that has been exacerbated by increasing demand due to high population growth, several fluxes of refugees, increasing economic development needs, increasing frequency and severity of drought events, and climate change (MoEnv 2014). Jordan's population increased from 6.1 million in 2010 to around 10.3 million in the middle of 2018 (DOS 2018), and despite a lower local growth rate of $2.2 \%$, the huge increase in population continues, being attributable in the main to sudden influxes of refugees from other countries, mainly Iraq and Syria, a process which creates enormous pressure on already-scarce and depleted water resources (Al-Karablieh and Salman 2016; Al-Shibli et al. 2017).

Despite Government efforts to manage the country's limited water resources and a relentless search for alternative supplies, the available water resources per capita fell from $500 \mathrm{~m}^{3}$ in the 1975 to less than $100 \mathrm{~m}^{3}$ in 2017 (Arsenault 2017; MWI 2016a, b, c, 2017; USAID 2018). Among all climatic risks, drought is the most threatening in the long term, as it represents a gradual natural hazard that has significant direct and indirect socio-economic and environmental impacts on all residents in a region (Aladaileh et al. 2019; Liamas and Custodio 2003; Sivakumar 2005). Several studies have highlighted the severity and impact of water stress in Jordan as being caused by climate change impacts (MoEnv 2014; Al Qatarneh et al. 2018; ElNaqa and Al-Shayeb 2009; Margane et al. 2004; Abdulla and Eshtawi 2015; Abdulla and Al Omari 2008). Among the effects noted have been a $70 \%$ loss in camel population, around a 70\% reduction in cereal harvests, more than 200 springs becoming dry, and drops in groundwater level at a rate of around $2 \mathrm{~m} /$ year, though in some highly depleted areas, the reduction can reach 5-20 m/year, decreasing the magnitude of base flow and flood flow in the main wadis (valleys) and reducing the main dams' storage to around half of capacity in the last 20 years. These impacts have led to increases in food imports, food insecurity, increases in desertification trends, frequent deterioration of land productivity, increases in health problems, increased migration from rural areas, reduction in investments, and even increased unemployment (Water Scarcity 2017; Battikhi 2013; Mohammad et al. 2015; Abu-Allaban et al. 2015; Al-Tabbal and Al-Zboon 2012).

A series of studies has indicated that the Jordan surface and groundwater basins are likely to experience more severe drought in the period 2031-2060 than in the period 1961-1990, with the expectation of increased severity of droughts, more frequent droughts and moderate droughts becoming severe droughts (Törnros and Menzel 2013; Al-Adamat et al. 2003; Al-Mashagbah and Al-Farajat 2013; Rahman et al. 2015). Successive droughts have occurred at least three times over the past 40 years, and the rate at which these occur is expected to increase every 20-25 years, with a regular average drought of 3 years and a severe drought every 6-7 years. These increases in droughts and further negative climate change effects in Jordan are thus expected to further decrease water availability by 15-20\% (El-Naser 2014; Goode et al. 2013; AlQinna et al. 2011; Rajsekhar and Gorelick 2017; Hajar et al. 2019).

In addition to issues with water governance in the form of lax enforcement of rules and regulations, a lack of equity and transparency has resulted in continuous mining of renewable groundwater resources, with extraction rates currently at $50 \%$ over safe yields, increasing water salinity, reducing water table levels, and increasing pumping costs (Salman and Al-Karablieh 2004). Efficient management of scarce water resources is thus an existential necessity (World Bank 2016), critical to the livelihoods and well-being of Jordan's people and essential to the country's lasting stability. Without securing its water assets, Jordan risks imminent economic slowdowns, health hazards, social disruptions, and serious conflicts over water resources (Al-Karablieh and Salman 2016; MWI 2016d, 2018).

In the last millennium, no special legislation dealing with drought was implemented, as it was not classified as a disaster; thus, only ad hoc interventions were implemented as actions after the occurrence of the event. Drought management in Jordan still lacks proactivity, apart from that directed primarily for relief, and it also lacks coordination, being managed by multiple different departments within the relevant institutions (MWI 2018). For example, the Ministry of Agriculture (MOA) established an Agriculture Risk Management Fund (ARMF) in 2009 to provide feed subsidies for those who were impacted by drought and initiated restocking programs that focused on providing supplementary feeds to safeguard livestock (MOA 2009). Similarly, the Ministry of Water and Irrigation (MWI) established several strategies, such as the National Water Strategy (2016-2025) (MWI 2016a) change policies to encourage a resilient water sector (MWI 2016d) in which drought could be handled through not only in terms of supply augmentation and management, including rationing of water services, but also with regard to demand management measures and the adoption of a public information policies. Despite all of these measures, however, the predicted scarcity problem remains a major challenge for water managers and the country at large (MWI 2016b, d).

In 2018, the MWI release the Water Sector Policy for Drought Management Strategy (MWI 2018) to establish a drought early warning unit to provide a monitoring system (MWI 2018). This outlined the measures required to achieve 
long-term national goals for water security, driven by outcomes based on previously adopted strategies, policies, and plans updated on the basis of results, which are now an integral part of the overall management efforts.

Recently, drought was included as a national crisis by the Jordanian National Center for Security and Crisis Management (NCSCM), established in 2015. The NCSCM's duties include coordinating and unifying all efforts made by national institutions to enable them to face national crises in various forms to help achieve more strategic adjustment processes and secure a stable and secure national environment. The NCSCM aims to achieve its mission by harnessing national potential and unifying the efforts of relevant national institutions to achieve professionalism in both preparation for and response to national crises, both natural and manmade, reducing effort, time, costs, and possible losses (NCSCM 2015). In 2017, the Government of Jordan thus delegated the responsibility for establishing and institutionalising the national disaster risk reduction (DRR) platform to the NCSCM.

Drought is a pervasive natural disaster that causes severe environmental, economic, health, and societal impacts. Jordan has witnessed several droughts recently, along with recurring summer heat waves, which are likely to be consequences of climate change and global warming; as surface and groundwater resources in Jordan are thus threatened, it is vital to develop adaptation planning based on vulnerability mapping that takes into account prolonged weather events such as drought, and this need justifies this research. The aim of this study is to generate a drought vulnerability map for the Jordanian groundwater system based on assessment of the climatic exposure, groundwater basin sensitivity and actual adaptive capacity at district level, and also to propose adaption measures based on groundwater sector impact chain analysis to improve the country's preparedness for likely future droughts.

\section{Methodology}

\subsection{Study Area}

The Hashemite Kingdom of Jordan, one of the Middle East and North Africa (MENA) countries, is located $80 \mathrm{~km}$ east of the Mediterranean Sea, between $29^{\circ} 11^{\prime}$ and $33^{\circ} 22^{\prime} \mathrm{N}$, and $34^{\circ} 19^{\prime}$ and $39^{\circ} 18^{\prime} \mathrm{E}$. The country as a whole covers an area of $89,318 \mathrm{~km}^{2}$, of which $88,794 \mathrm{~km}^{2}$ is considered land, with territorial waters covering $524 \mathrm{~km}^{2}$, and including the Dead Sea, and the Gulf of Aqaba at $430 \mathrm{~km}^{2}$ and $94 \mathrm{~km}^{2}$, respectively. The land area consists, topographically, of $550 \mathrm{~km}^{2}$ of heights, $10,000 \mathrm{~km}^{2}$ of plains, $8244 \mathrm{~km}^{2}$ of the Rift valley, and $70,000 \mathrm{~km}^{2}$ of desert, including the Badia (Fig. 1).
Jordan is a semi-arid and drought-prone country that is heavily influenced by the range of mountains to the West (MoEnv 2016). The western part of Jordan, the Highlands, has a Mediterranean climate characterised by a hot, dry summer and a cool, wet winter, which are separated by two short transitional periods. This generates two contrasting seasons, the relatively mild and rainy months from October to May, and a hot and dry summer during the rest of the year. During the summer months, temperatures average around $32{ }^{\circ} \mathrm{C}$ with recorded highs of up to $49^{\circ} \mathrm{C}$. In the winter, temperatures drop markedly, with averages of around $13{ }^{\circ} \mathrm{C}$. The dry desert and steppe regions of the country receive less than $100 \mathrm{~mm}$ of rain a year, but the quantity of precipitation increases with the rise in elevation in the highlands east of the Jordan Valley, ranging from $300 \mathrm{~mm}$ to more than $500 \mathrm{~mm}$ in the south and north, respectively). Frost and occasional snow can be seen in Amman during the height of the winter season, and in general, the farther inland from the Mediterranean Sea an area of the country lies, the greater the contrast there between the two seasons, and the less rainfall received. Jordan is thus mostly arid (90\%) and semi-arid (8\%), with diverse agro-ecological zones (MoEnv 2016).

Potential evapotranspiration typically exceeds rainfall. Approximately $92 \%$ of rainfall evaporates, while only $5.4 \%$ recharges the groundwater and the remaining $2.4 \%$ becomes surface water (Salameh and Bannayan 1993). The country can be classified into three main physiographical regions: the Lowlands (Ghor Region), the Highlands, and the Desert lands (Badia), which vary in elevation from $1854 \mathrm{~m}$ above mean sea level (amsl) at the Um Dami Mountain to $417 \mathrm{~m}$ below mean sea level at the Dead Sea (GLOWA 2013). The Lowlands, a part of the Great Rift Valley (JRV), extend from the northwestern part of the country towards the south western corner, with elevations ranging from $197 \mathrm{~m}$ below msl in the north to 417 below msl at the Dead Sea. The Highlands and Marginal Steppes region extend north-south to the east of the JRV, stretching from the Yarmouk River in the north to Ras El-Naqab in the south. The mountains peaks' elevations vary from $1150 \mathrm{~m}$ amsl in Ras Muneef to $1365 \mathrm{~m}$ amsl at $\mathrm{Al}-$ Shoubak, and the height exceeds $1500 \mathrm{~m}$ at El-Qurain. The Desert lands extend north-south from the eastward foot of the Highlands, with elevations ranging from 600 to $750 \mathrm{~m}$ amsl.

Jordan ratified the United Nations Framework Convention on Climate Change in 1993 and the Kyoto Protocol in 2003. Analysis of historical data associated with the climate state in Jordan as published in the third national communication report showed that there has been a decline in precipitation at a rate of $1.2 \mathrm{~mm}$ per year, as well as increases in temperature of an average of $0.02{ }^{\circ} \mathrm{C}$ annually (MoEnv 2016). 


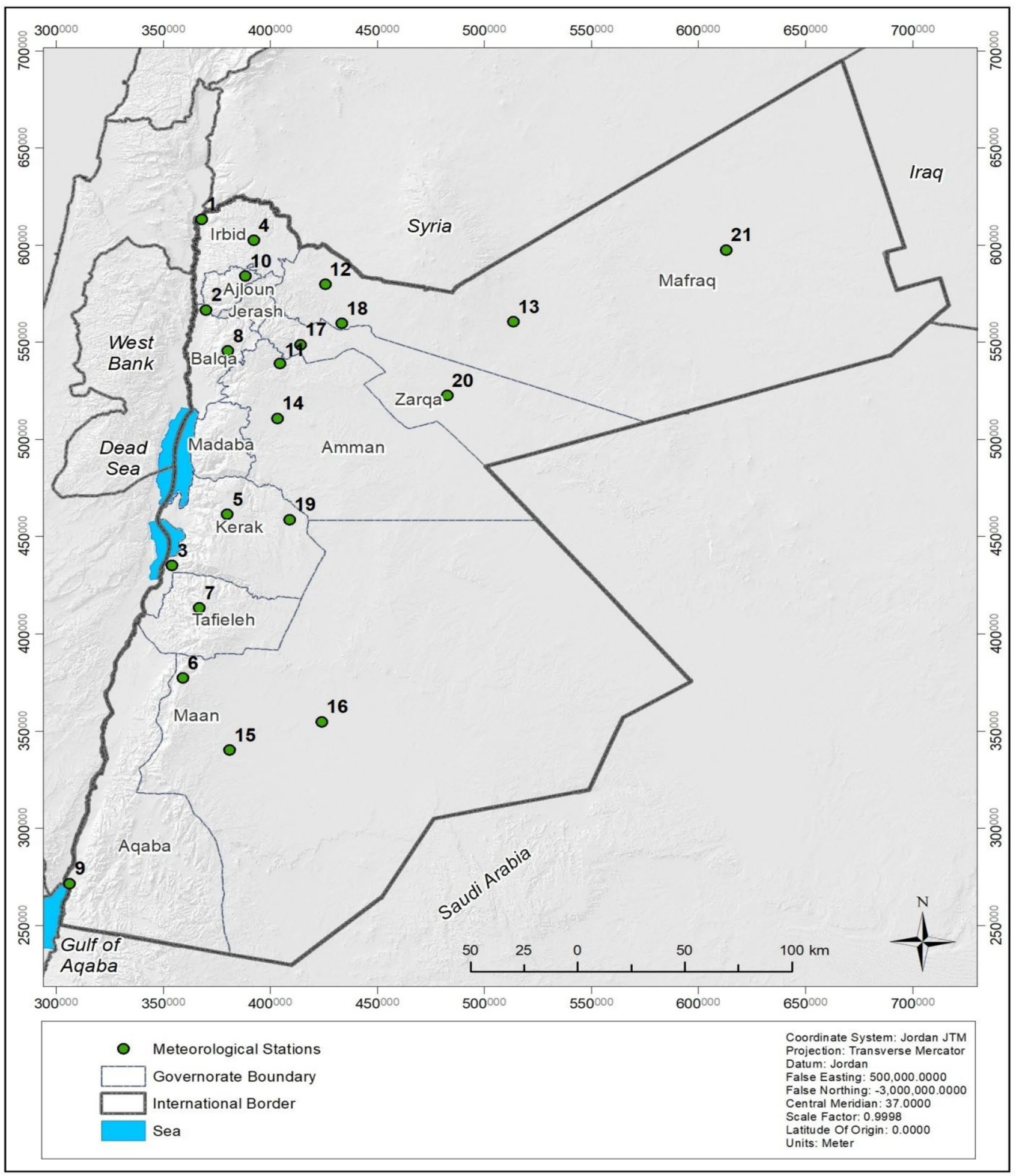

Fig. 1 The map of the Hashemite Kingdom of Jordan as a study area

\subsection{Water Sector Status at Jordan}

The water sector is regulated by the Ministry of Water and Irrigation By-Law No. 14 (2014), Water Authority of Jordan
Law No. 18 (1988) and its amendments, and Jordan Valley Authority By-Law No. 30 (2001). Other relevant laws include Public Health Law No. 47 (2008), Environmental Protection Law No. 85 (2006), and Groundwater By-Law 
No. 85 (2002) and its amendments. The amendments to By-Law No. 14 (2014) are the instrument by which MWI assumes policy and strategic leadership of the water sector (Al-Karablieh and Salman 2016; Molle et al. 2017).

Jordan's renewable water resources are limited and insufficient to national demand. Jordan has just 15 surface water basins and 12 groundwater basins, with about $40 \%$ of total water resources being shared water (Figs. 2, 3). The quantity of renewable water resources available for different purposes is around $853 \mathrm{mcm}$ annually, yet the total amount used for all sectors was $1053.6 \mathrm{mcm}$ for 2017 , while the estimated water demand quantity for all sectors now is $1412 \mathrm{mcm}$. The Government has tried to compensate for the difference between water demand and supply by providing implementing all possible techniques to harvest water and reuse unconventional water as much as possible (Wolff et al. 2012). Currently, there are 12 dams with $335.3 \mathrm{mcm}$ total capacity; however, their storage was only $227 \mathrm{mcm}$ for 2017. In addition, 361 desert dams, earth and concrete ponds, have been designed to hold $111.7 \mathrm{mcm}$, and the government has constructed 34 wastewater treatment plants with a total capacity of $0.639 \mathrm{mcm} /$ day (MWI 2017).

The tremendous need for water in all sectors is being met by groundwater abstraction above the safe yield, which is imposing groundwater depletion beyond recharge rates along with quality deterioration. Deficits in groundwater are clear at all basins, with the groundwater levels in the main aquifers dropping at a rate of $2 \mathrm{~m} /$ year; however, the decline in some depleted areas has reached as high as $20 \mathrm{~m}$ (Fig. 2). It is important to note that the number of working wells in Jordan exceeds 3200 , yet many further illegal wells are being drilled every year, with the estimates for non-revenue water reaching as high as $48 \%$ for 2017 .

\subsection{Combined Drought Index (CDI)}

Daily rainfall, air temperature and weather data for 21 meteorological stations were obtained from the Jordan Meteorological Department (JMD). This climatic data represent the long-term records from 1980 to 2017. The characteristics of the meteorological stations are presented in Table 1.

There seasonal drought indices were used to calculate the combined drought index, those were precipitation drought index (PDI), temperature drought index (TDI), and vegetation drought index (VDI). Both PDI and TDI are indicatives for meteorological-climatic droughts, while the VDI reflects the vegetation stress caused by adverse climatic and hydrological factors. The PDI, TDI, and VDI indices were calculated using the following equations (Balint et al. 2011):

$$
\mathrm{PDI}_{i, m}=\frac{\frac{1}{\mathrm{IP}} \sum_{j=0}^{\mathrm{IP}-1} P_{i,(m-j)}^{*}}{\frac{1}{(\mathrm{n} \times \mathrm{IP})} \sum_{k=1}^{n}\left[\sum_{j=0}^{\mathrm{IP}-1} P_{(m-j), k}^{*}\right]} \times \sqrt{\left(\frac{\mathrm{RL}_{m, i}^{(P *)}}{\frac{1}{\mathrm{n}} \sum_{k=1}^{n} \mathrm{RL}_{m, k}^{(P *)}}\right)},
$$

$$
\mathrm{TDI}_{i, m}=\frac{\frac{1}{\mathrm{IP}} \sum_{j=0}^{\mathrm{IP}-1}\left[T_{i,(m-j)}^{*}\right]}{\frac{1}{(n \times \mathrm{IP})} \sum_{k=1}^{n}\left[\sum_{j=0}^{\mathrm{IP}-1} T_{(m-j), k}^{*}\right]} \times \sqrt{\left(\frac{\mathrm{RL}_{m, i}^{(T * *)}}{\frac{1}{n} \sum_{k=1}^{n} \mathrm{RL}_{m, k}^{(T *)}}\right)},
$$

$$
\begin{aligned}
\mathrm{VDI}_{i, m}= & \frac{\frac{1}{\mathrm{IP}} \sum_{j=0}^{\mathrm{IP}-1} \mathrm{NDVI}_{i,(m-j)}^{*}}{\frac{1}{(n \times \mathrm{IP})} \sum_{k=1}^{n}\left[\sum_{j=0}^{\mathrm{IP}-1} \mathrm{NDVI}_{(m-j), k}^{*}\right]} \\
& \times \sqrt{\left(\frac{\mathrm{RL}_{m, i}^{(\mathrm{NDVI} *)}}{\frac{1}{n} \sum_{k=1}^{n} \mathrm{RL}_{m, k}^{(\mathrm{NDVI} *)}}\right)},
\end{aligned}
$$

where $P^{*}$ is the modified monthly precipitation amount, $T^{*}$ is the modified monthly temperature, NDVI* is the modified monthly average normalised difference vegetation index, IP is the interest period (6 months in this case), RL $(P)$ (run length) is the maximum number of successive months below long-term average rainfall in the interest period, RL $(T)$ is the maximum number of successive months above long-term average temperature in the IP, RL (NDVI) is the maximum number of successive months below long-term average NDVI in the IP, $\mathrm{n}$ is the number of years with relevant data, $j$ is a summation parameter for the IP, and $k$ is the summation parameter covering the years for which relevant data are available (SWALIM 2011).

The normalised difference vegetation index (NDVI) values at a spatial resolution of $8 \mathrm{~km}$ were computed using the following equation (Kogan 1990):

$\mathrm{NDVI}=\frac{\mathrm{NIR}-R}{\mathrm{NIR}+R}$

where NIR is the near-infrared response, $R$ is the visible red portion of the spectrum bands of the Advanced Very High Resolution Radiometer (AVHRR) at the National Oceanic and Atmospheric Administration (NOAA). The data were provided by Global Inventory Modeling and Mapping Studies (GIMMS) and downloaded from the University of Maryland Global Land Cover Facility Data Distribution centre (http://www.glcf.umiacs.umd.edu/data/gimms/).

The combined drought index (CDI) was computed as a weighted average of the three seasonal drought indices, as in Eq. (5). The weighs were assigned according to Balint et al. (2011) based on partial correlation analyses as 50\%, 25\%, and $25 \%$ for precipitation drought index (PDI), temperature drought index (TDI), and vegetation drought index (VDI), respectively. The higher weight assigned to PDI is an indication for the importance as a determinant drought factor as compared to temperature and vegetation drought indices.

$$
\mathrm{CDI}_{i, m}=0.5 \times \mathrm{PDI}_{i, m}+0.25 \times \mathrm{TDI}_{i, m}+0.25 \times \mathrm{VDI}_{i, m} \text {. }
$$




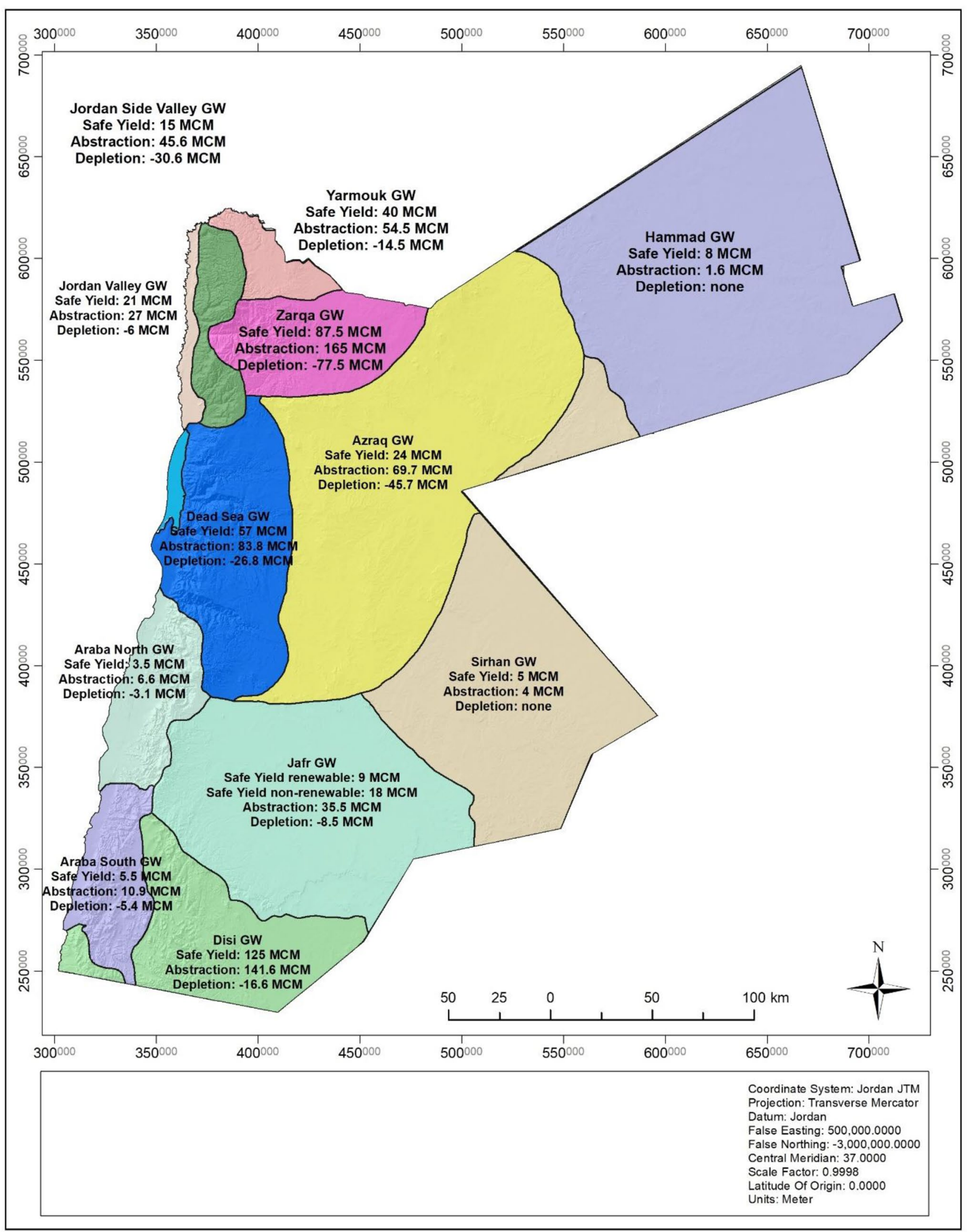

Fig. 2 Groundwater spatial map and status in Jordan for the year 2017 (modified after (MWI 2017)) 
Fig. 3 Groundwater system vulnerability determination sketch

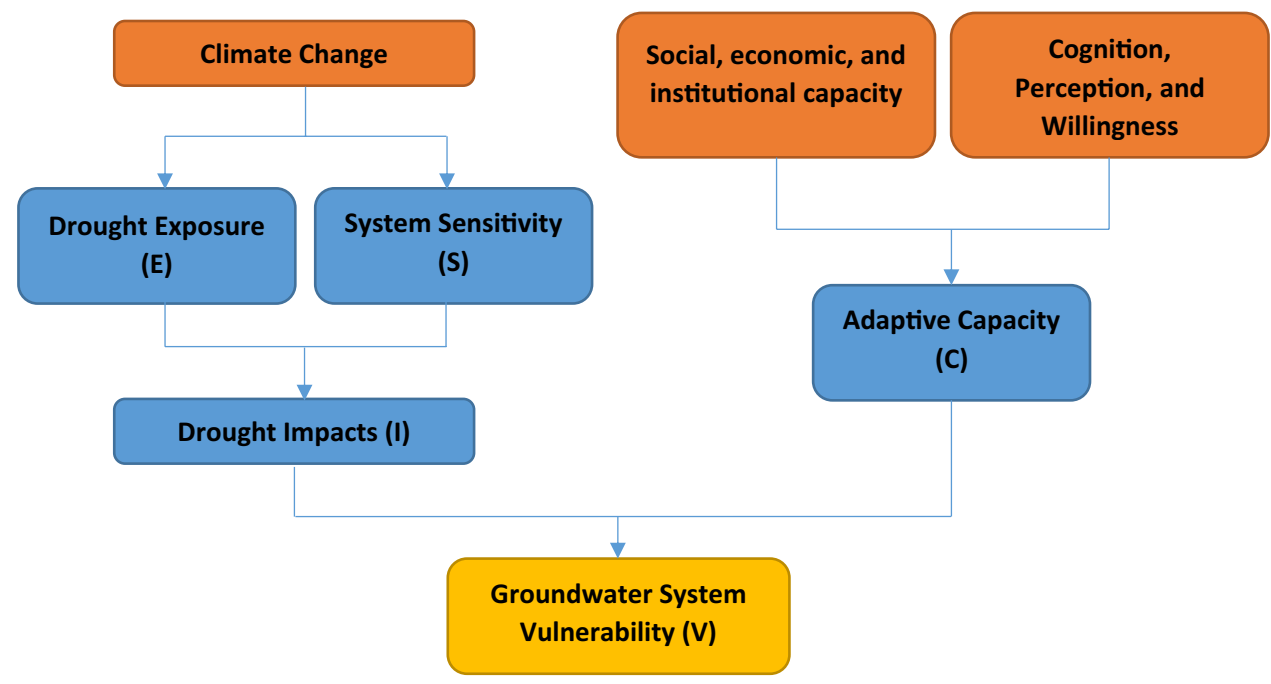

Table 1 Statistical summary of annual precipitation data by station
Table 2 Adopted CDI drought categories

\begin{tabular}{|c|c|c|c|c|c|c|c|c|}
\hline \multirow[t]{2}{*}{ No. } & \multirow[t]{2}{*}{ Station name } & \multirow[t]{2}{*}{ Altitude (m) } & \multicolumn{3}{|c|}{ Precipitation (mm) } & \multicolumn{3}{|c|}{ Temperature $\left({ }^{\circ} \mathrm{C}\right)$} \\
\hline & & & Mean annual & Min & Max & Max & Min & Mean \\
\hline 1 & Baqura & -170 & 392.4 & 174.3 & 918.3 & 33.6 & 10.2 & 22.6 \\
\hline 2 & Deir Alla & 330 & 282.3 & 117.0 & 599.0 & 35.0 & 11.5 & 24.3 \\
\hline 3 & Ghor Safi & -350 & 72.4 & 18.3 & 151.8 & 36.9 & 13.8 & 25.8 \\
\hline 4 & Irbid & 616 & 459.6 & 216.8 & 912.9 & 29.1 & 5.8 & 18.3 \\
\hline 5 & Rabba & 920 & 337.3 & 138.0 & 606.0 & 27.7 & 4.3 & 16.9 \\
\hline 6 & Shoubek & 1365 & 251.6 & 95.0 & 482.0 & 24.6 & 0.7 & 13.3 \\
\hline 7 & Tafieleh & 1200 & 203.8 & 85.0 & 358.0 & 27.1 & 3.4 & 16.1 \\
\hline 8 & Salt & 796 & 550.1 & 246.0 & 1130. & 27.8 & 3.9 & 16.9 \\
\hline 9 & Aqaba & 51 & 25.6 & 1.0 & 86.0 & 35.5 & 11.8 & 24.9 \\
\hline 10 & Ras Munief & 1150 & 463.9 & 217.0 & 913.0 & 25.5 & 1.4 & 14.8 \\
\hline 11 & Amman Airport & 790 & 254.2 & 111.0 & 548.0 & 30.0 & 4.8 & 18.2 \\
\hline 12 & Mafreq & 686 & 154.8 & 65.0 & 301.0 & 28.8 & 4.6 & 17.3 \\
\hline 13 & Safawi H5 & 674 & 70.1 & 16.0 & 158.0 & 33.6 & 5.1 & 19.9 \\
\hline 14 & Queen AIA & 722 & 155.9 & 56.0 & 326.0 & 28.0 & 4.4 & 16.9 \\
\hline 15 & Maan & 1069 & 41.2 & 12.0 & 108.0 & 30.2 & 4.5 & 18.2 \\
\hline 16 & Al-Jafr & 865 & 31.4 & 1.0 & 135.0 & 31.0 & 5.1 & 13.1 \\
\hline 17 & Zarqa & 664 & 129.5 & 48.0 & 258.0 & 30.7 & 5.8 & 19.2 \\
\hline 18 & Wadi Dhuleil & 575 & 141.0 & 54.5 & 276.0 & 30.5 & 5.2 & 18.4 \\
\hline 19 & Qatraneh & 730 & 97.3 & 25.0 & 156.0 & 28.6 & 5.1 & 17.7 \\
\hline 20 & Azraq South & 610 & 54.0 & 9.0 & 149.0 & 32.4 & 5.8 & 19.8 \\
\hline 21 & Reweished H4 & 683 & 81.2 & 16.0 & 168.0 & 32.9 & 4.4 & 19.8 \\
\hline
\end{tabular}

Drought severity at each meteorological station was classified into five drought categories, again as recommended by Balint et al. (2013), and these are presented in Table 2. The probability of occurrence under each category was estimated by dividing the count of drought events per category over the total count of drought events. 


\subsection{Generating a Drought Vulnerability Map}

Before commencing vulnerability analysis, an "Impact Chain Framework" was drafted based on the theory of interaction between exposure, sensitivity, and adaptive capacity factors controlling or affecting the groundwater systems in Jordan. The framework was generated based on multiple stakeholders' assessment, with stakeholders ranging from governmental ministries through academia, and research centres.

Vulnerability is a function of the character, magnitude, and rate of drought to which a system is exposed, along with its sensitivity, and adaptive capacity (Al-Bakei et al. 2019). Jordan's groundwater drought vulnerability was assessed for the whole country based on a scoring technique for drought impacts (I) as identified through both drought exposure (E) and the sensitivity (S) of the country's groundwater sector, in addition to existing adaptive capacity (C) (Fig. 3).

Figure 4 shows the impact chain framework for the drought vulnerability assessment for the groundwater systems in Jordan as generated based on multiple stakeholders' assessment. The framework identifies the factors to consider in the vulnerability assessment. Exposure, the degree of climatic stress upon a groundwater system, was categorised by merging two factors: drought severity and probability of occurrence derived from CDI Table 3).

Groundwater sensitivity, the degree to which the groundwater system is affected by climate-related variables, was determined at each basin using a cumulative weighted function based on existing groundwater conditions (Eq. 1). In this study and based on generated impact chain framework, the following factors were implemented in the sensitivity analyses: groundwater safe yield, abstraction, and depletion:

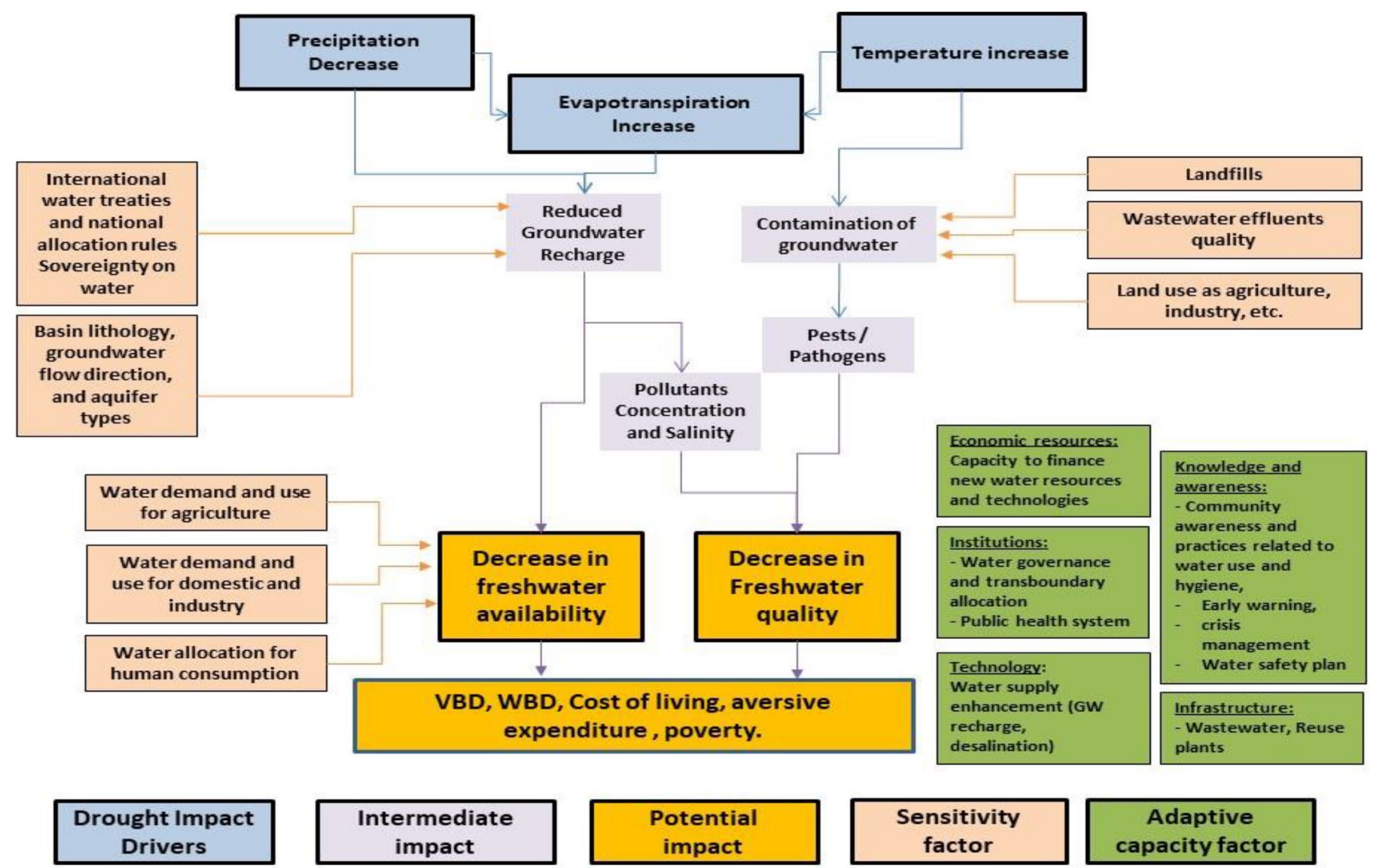

Fig. 4 Impact chain framework for the drought vulnerability assessment of groundwater systems in Jordan

Table 3 Scoring of drought exposure

\begin{tabular}{llllll}
\hline & Score 1 & Score 2 & Score 3 & Score 4 & Score 5 \\
\hline $\begin{array}{l}\text { Drought severity } \\
\begin{array}{l}\text { Probability of } \\
\text { occurrence (Pr) }\end{array}\end{array}$ & $\mathrm{CDI} \leq 1$ & $1.0>\mathrm{CDI}>0.8$ & $0.80>\mathrm{CDI}>0.6$ & $0.6>\mathrm{CDI}>0.4$ & $\mathrm{CDI} \leq 0.4$ \\
\hline
\end{tabular}


Cumulative weighted function $=\frac{\sum_{i=1}^{n} W_{i} \times F_{i}}{\sum_{i=1}^{n} W_{i}}$,

where $F_{i}$ is each individual factor and $W_{i}$ is the weight assigned to each factor.

The individual groundwater basin adaptive capacity, the ability of system to adjust to climate change and moderate potential damage and to cope with the consequences, was estimated using a cumulative weighted function of the factors included in Table 4 as recommended and generated by the impact chain framework. These include economic, institutional, technological, knowledge and awareness based, and infrastructure aspects.

Groundwater sector vulnerability to drought was assessed using a scoring technique by which the vulnerability emerged as the ratio of impact to adaptive capacity as discussed in impact chain framework in Fig. 3. The scores were estimated for each vulnerability class based on expert judgments of the associated impacts (I) and sensitivity (S) of the country's water sector, taking into account existing adaptive capacity (C). Five water vulnerability categories were suggested: extremely vulnerable, highly vulnerable, moderately vulnerable, low vulnerability, very low vulnerability (Table 5).

\subsection{Mapping Drought Impacts}

Simple Kriging interpolation was generated within ArcGIS (10.5) software. The long-term drought vulnerability map was implemented in four steps: the determination of distribution type; characterisation of spatial distribution through computation of semi-variance clouds in all directions; selection and construction of the best empirical fit; prediction at unsampled points using a point Kriging technique (Goovaerts 1997, 1999; Selker et al. 1999; Salman et al. 2009; Bancheri et al. 2018).

\subsection{Proposing Drought}

Assessing drought vulnerability through the application of a multi-stakeholder approach encourages the identification of sustainable adaptation strategies that could significantly improve infrastructure resilience. A long list of possible adaptation options/measures was thus proposed by multidisciplinary stakeholders in response to the identified hazards and vulnerabilities in groundwater systems. The measures were categorised under seven different themes: (1) demand management, (2) supply side management, (3) cooperation with neighbouring countries and the international community, (4) integrated water information and database development, (5) training, awareness, and capacity building, (6) innovation and technology, and (7) Strategic planning/ Policy/Legislations/Government Participation.

Table 4 Groundwater basin adaptive capacity factors included in the vulnerability assessment

\begin{tabular}{ll}
\hline Enabling environment & Indicators \\
\hline Politics & Transboundary agreements, etc. \\
Economics & Capacity of investments at district level, existence of mega projects to reduce the abstraction of the \\
& groundwater basin either through water saving controls or aquifer recharge, etc. \\
Institutions & Existence of monitoring and regulatory system for water use at municipality level, water governance, etc. \\
Planning & Existence of local planning to develop the groundwater systems at municipality level \\
Resources & Availability of alternative water sources either surface or non-conventional water
\end{tabular}

Table 5 Scoring of drought vulnerability

\begin{tabular}{rccccc}
\hline \multicolumn{5}{c}{ Drought impact score } \\
\hline $\begin{array}{l}\text { Adaptive } \\
\text { Capacity }\end{array}$ & $0.1-1$ & $1.1-2$ & $2.1-3$ & $3.1-4$ & $4.1-5$ \\
Score & & & & & \\
\hline $0.1-1$ & Very Low & Low & Low & Moderate & Moderate \\
$1.1-2$ & Low & Low & Moderate & Moderate & Moderate \\
$2.1-3$ & Low & Moderate & Moderate & High & High \\
$3.1-4$ & Moderate & Moderate & High & High & Extreme \\
$4.1-5$ & Moderate & High & High & Extreme & Extreme \\
\hline
\end{tabular}


Table 6 CDI values regarding each station and year from 1980 to 2017

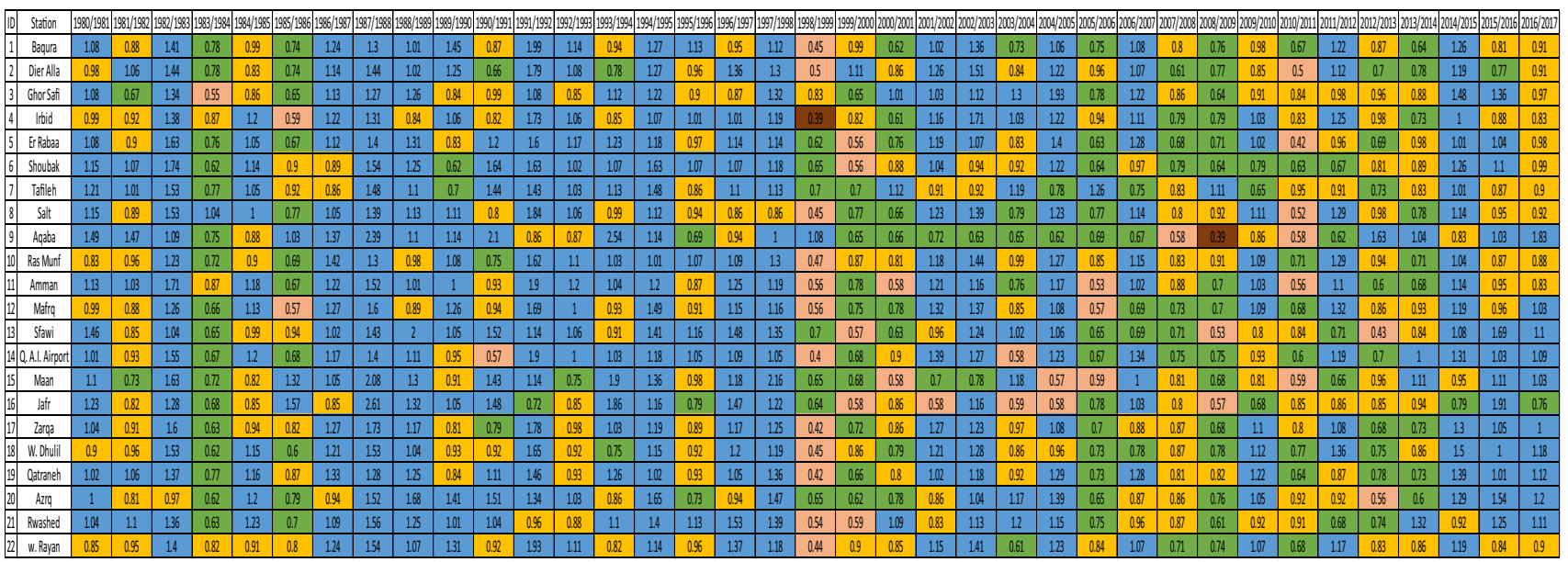

\begin{tabular}{|c|c|}
\hline Drought category & CDI value \\
\hline No drought & $>1.0$ \\
\hline Mild & $1.0-0.8$ \\
\hline Moderate & $0.8-0.6$ \\
\hline Severe & $0.6-0.4$ \\
\hline Extreme & $<0.4$ \\
\hline & \\
\hline
\end{tabular}

\section{Results}

\subsection{Generating the Combined Drought Index (CDI)}

Based on Eqs. (1-4), the seasonal combined drought indices were generated for all meteorological stations from the period 1980-2017. The CDI magnitude varies significantly by the year and station, ranging from extreme drought to no drought, as indicated by associated CDI scores from 0.39 to 2.61 (Table 6). Almost all regions suffer from drought to some degree, but not all the regions experience droughts at the same time. Temporal distribution and frequency of dry periods vary markedly among the regions, and in terms of timescale, the longest dry spell duration was 13 years, at Aqaba. On the other hand, as the table shows, while the longest drought periods were during the period from 2005 to 2014 , most parts of the country witnessed severe drought during the period 1998-2000.

Since drought in Jordan is a temporal and spatial phenomenon that varies by location (station) and year of impact, it is thus inconvenient to measure the average CDI magnitudes for all years (drought and non-drought years), as this would likely be around one. To indicate the exact probability of drought events in each drought category, drought probabilities were thus determined for each station by taking into account the number of events in each category divided by total drought events (Table 7). Results indicate that the most common or frequent occurring droughts range from mild to moderate in category, as indicated by the highest probability, while severe and extreme droughts are rare.
The average magnitude for each drought category was calculated based on sum of CDIs per category over the total number of drought events per category (Table 8 ). The results indicate that all stations had similar CDI values for the mild and moderate drought categories; however, the magnitudes vary significantly at both severe and extreme drought categories which indicates that severe and extreme drought cases are more site specific (i.e. micro-scale impacts).

\subsection{Drought Vulnerability Map}

Based on the scores for both district and groundwater basin levels, a drought vulnerability map was generated (Fig. 5). The generated scores vary from 2.1 to 4.6 ranging from moderate to high vulnerability. The highest scores and thus most vulnerable basins are Azraq and Dead Sea groundwater basins. The high generated vulnerability scores are derived from the moderate to high impacts and associated by moderate to low adaptive capacity. Both Azraq and Dead Sea groundwater basins are categorised within the highest impact and low adaptive capacity scores.

\section{Discussion}

Based on the generated groundwater vulnerability map that is derived from CDI assessment along with real groundwater sensitivity and actual adaptive capacity analyses, the country of Jordan is experiencing both micro- and macro-drought events with varying spatial and temporal range of impacts. 
Table 7 Probability of drought occurrence at each station

\begin{tabular}{|c|c|c|c|c|c|c|c|}
\hline \multirow[t]{2}{*}{ ID } & \multirow[t]{2}{*}{ Station } & \multirow[t]{2}{*}{$\begin{array}{l}\text { Probability of drought } \\
\text { occurrence (drought } \\
\text { events/total events) }\end{array}$} & \multicolumn{4}{|c|}{$\begin{array}{l}\text { Probability of drought under different } \\
\text { category (drought event per category/ } \\
\text { total drought events) }\end{array}$} & \multirow[t]{2}{*}{$\begin{array}{l}\text { Overall } \\
\text { drought } \\
\text { probability }\end{array}$} \\
\hline & & & Mild & Moderate & Severe & Extreme & \\
\hline 1 & Baqura & 0.54 & 0.55 & 0.40 & 0.05 & 0.00 & 1.50 \\
\hline 2 & Dier Alla & 0.51 & 0.42 & 0.47 & 0.11 & 0.00 & 1.68 \\
\hline 3 & Ghor Safi & 0.54 & 0.70 & 0.25 & 0.05 & 0.00 & 1.35 \\
\hline 4 & Irbid & 0.49 & 0.67 & 0.22 & 0.06 & 0.06 & 1.50 \\
\hline 5 & Er Rabaa & 0.46 & 0.41 & 0.47 & 0.12 & 0.00 & 1.71 \\
\hline 6 & Shoubak & 0.51 & 0.47 & 0.47 & 0.05 & 0.00 & 1.58 \\
\hline 7 & Tafileh & 0.51 & 0.58 & 0.42 & 0.00 & 0.00 & 1.42 \\
\hline 8 & Salt & 0.51 & 0.58 & 0.32 & 0.11 & 0.00 & 1.53 \\
\hline 9 & Aqaba & 0.54 & 0.30 & 0.55 & 0.10 & 0.05 & 1.90 \\
\hline 10 & Ras Munf & 0.51 & 0.68 & 0.26 & 0.05 & 0.00 & 1.37 \\
\hline 11 & Amman & 0.43 & 0.38 & 0.38 & 0.25 & 0.00 & 1.88 \\
\hline 12 & Mafrq & 0.54 & 0.50 & 0.35 & 0.15 & 0.00 & 1.65 \\
\hline 13 & Sfawi & 0.49 & 0.44 & 0.39 & 0.17 & 0.00 & 1.72 \\
\hline 14 & Q. A. I. Airport & 0.41 & 0.27 & 0.53 & 0.20 & 0.00 & 1.93 \\
\hline 15 & Maan & 0.54 & 0.35 & 0.45 & 0.20 & 0.00 & 1.85 \\
\hline 16 & Jafr & 0.62 & 0.43 & 0.35 & 0.22 & 0.00 & 1.78 \\
\hline 17 & Zarqa & 0.51 & 0.58 & 0.37 & 0.05 & 0.00 & 1.47 \\
\hline 18 & W. Dhulil & 0.57 & 0.52 & 0.43 & 0.05 & 0.00 & 1.52 \\
\hline 19 & Qatraneh & 0.43 & 0.56 & 0.38 & 0.06 & 0.00 & 1.50 \\
\hline 20 & Azrq & 0.54 & 0.50 & 0.45 & 0.05 & 0.00 & 1.55 \\
\hline 21 & Rwashed & 0.43 & 0.50 & 0.38 & 0.13 & 0.00 & 1.63 \\
\hline 22 & Wadi Rayan & 0.54 & 0.75 & 0.20 & 0.05 & 0.00 & 1.30 \\
\hline
\end{tabular}

Italic values indicate $P<0.05$

\begin{tabular}{lllllll}
\hline ID & Station & Non & Mild & Moderate & Severe & Extreme \\
\hline 1 & Baqura & 1.24 & 0.91 & 0.71 & 0.45 & 0.00 \\
2 & Dier Alla & 1.26 & 0.90 & 0.73 & 0.50 & 0.00 \\
3 & Ghor Safi & 1.25 & 0.90 & 0.68 & 0.55 & 0.00 \\
4 & Irbid & 1.20 & 0.88 & 0.73 & 0.59 & 0.39 \\
5 & Er Rabaa & 1.21 & 0.92 & 0.69 & 0.49 & 0.00 \\
6 & Shoubak & 1.27 & 0.91 & 0.67 & 0.56 & 0.00 \\
7 & Tafileh & 1.21 & 0.89 & 0.72 & 0.00 & 0.00 \\
8 & Salt & 1.22 & 0.90 & 0.76 & 0.49 & 0.00 \\
9 & Aqaba & 1.44 & 0.87 & 0.67 & 0.58 & 0.39 \\
10 & Ras Munf & 1.21 & 0.89 & 0.72 & 0.47 & 0.00 \\
11 & Amman & 1.21 & 0.89 & 0.70 & 0.56 & 0.00 \\
12 & Mafrq & 1.26 & 0.91 & 0.71 & 0.57 & 0.00 \\
13 & Sfawi & 1.28 & 0.89 & 0.68 & 0.51 & 0.00 \\
14 & Q. A. I. Airport & 1.21 & 0.93 & 0.69 & 0.52 & 0.00 \\
15 & Maan & 1.36 & 0.89 & 0.71 & 0.58 & 0.00 \\
16 & Jafr & 1.45 & 0.85 & 0.73 & 0.58 & 0.00 \\
17 & Zarqa & 1.24 & 0.88 & 0.70 & 0.42 & 0.00 \\
18 & W. Dhulil & 1.27 & 0.91 & 0.73 & 0.45 & 0.00 \\
19 & Qatraneh & 1.20 & 0.87 & 0.72 & 0.42 & 0.00 \\
20 & Azrq & 1.32 & 0.90 & 0.69 & 0.56 & 0.00 \\
21 & Rwashed & 1.21 & 0.91 & 0.69 & 0.57 & 0.00 \\
22 & Wadi Rayan & 1.27 & 0.87 & 0.69 & 0.44 & 0.00 \\
\hline & & & & &
\end{tabular}

Table 8 Average drought magnitude at each station 


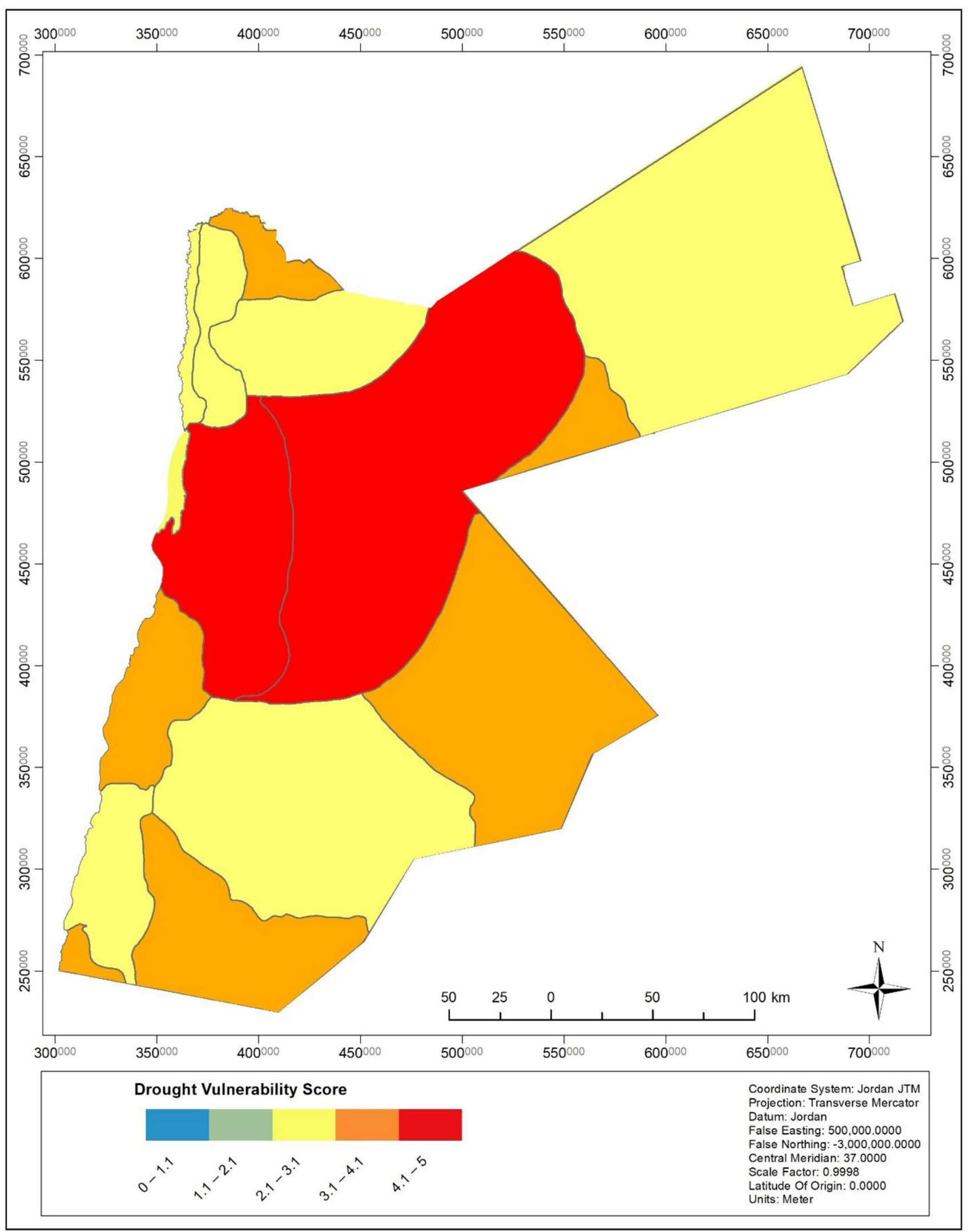

Fig. 5 Drought vulnerability score map for Jordan 
At a regional scale, the long-term droughts are more likely to range from mild to moderate categories with duration that may last up to 12 consecutive years. However, at microscale, the drought impacts may reach severe and extreme levels with durations up to five consecutive years as at Irbid and Aqaba.

Along with the spatial and temporal variability in drought exposure, the variability in the degree to which the groundwater system is affected by climate-related variables complicates the vulnerability assessment. The groundwater sensitivity factors may include the decrease in freshwater availability as a function of basin lithology, groundwater flow direction, aquifer type, international water treaties, national allocation rules, water demand and use for all sectors, and water allocation for human consumption, in addition to groundwater quality factors which are a function of various different anthropic uses (e.g. landfill, wastewater treatments effluent quality) and land use. In this study, the use of simple indicators as in this case provided a real estimation based on actual characterization of the existing groundwater basins including groundwater safe yield, abstraction, and depletion.

The generated drought vulnerability map indicates that the whole country is subject to drought events, with anywhere between moderate to high vulnerability. Although the CDI values indicate that transitional zones with rainfall trend shifts are the most susceptible regions for high drought impacts, the high groundwater sensitivity and weak adaptive capacities caused by weak water governance and limited management plans at both ministry and municipality level justify the extreme vulnerability at the Azraq and Dead Sea groundwater basins, based on the fact that these basins have very high abstraction with intensive depletion rates.

On the other hand, the Zarqa groundwater basin displays moderate vulnerability despite suffering from high abstraction, reaching $165 \mathrm{mcm}$ with a depletion rate of $77.5 \mathrm{mcm}$; the basin vulnerability is moderated due to the presence of investments at district level associated with mega projects to generate alternative water sources and local plans to reduce water loss.

The vulnerability map also indicates that Disi and Yarmouk groundwater basins are highly vulnerable to drought, which is attributable to political aspects, particularly weak enforcement of transboundary agreements. The groundwater basin thus is being either depleted heavily by neighbouring countries and/or close to feed ports for surface water used in building large water dams.

Based on the generated vulnerability map, the individual groundwater basin adaptive capacity should be strengthened to cope with the drought consequences. This includes not only political agreements, but rather improving the existing institutional arrangement of the monitoring and regulatory systems towards water governance and proper planning at municipality level. Searching and managing alternative resources might reduce the drought impacts but this requires high investment capacity at both district and governorate levels.

Although none of the government ministries holds the specific remit for drought risk management units, several activities are involved with drought and its management in one way or another. Aspects related to data collection and analysis, monitoring and forecasting, and development of drought mitigation and action plans require such a unit to be established. Until that point, all of the following ministries must be considered:

- The Ministry of Water and Irrigation, through its responsibilities for hydrologic analysis and related modelling, as well as in its central and field offices in which it implements methods to control water, use it efficiently, and protect its quantity and quality.

- The Ministry of Agriculture, through its efforts to combat desertification, conduct research, and provide extended services related to the water use and efficiency. There are two units concerned with parts of the drought management cycle: The Drought Management Unit (DMU) at the National Centre of Agricultural Research and Extension (affiliated with MOA) and the Agricultural Risk Management Fund (ARMF).

- The Ministry of Higher Education, through its research dealing with water shortages and studies related to better use of water and protection of quality.

- The Ministry of Transport/Directorate of Meteorology, through its prediction modelling activities with regard to precipitation, temperature, moisture, wind, and related meteorological data.

- The Ministry of Environment through a number of programs focused on desertification and climate change, as well as its involvement in the protection and monitoring of water quality.

- The Ministry of Planning through the Department of Statistics, which issues periodical reports and statistically indicative data related to drought and agricultural production.

Current drought management in Jordan is challenged by a weak link between information, available climate tools and decision-making for searching and adopting the best drought management plan at all levels. Neither there is a special legislation dealing with drought, nor preparedness is available in a manner commensurate. The Government of Jordan should develop and implement national drought management plans based on proactive risk management rather than crisis management to address various types of drought in coordination with the public and private sectors. The Government of Jordan should develop, coordinate and evaluate 
Table 9 Proposed drought management measures for the water sector in Jordan

Demand management

Improve domestic water distribution networks, including reducing water losses and energy efficiency in pumping

Economic incentives for reduction of excess water use in all sectors

Increase the use of non-conventional water resources (treated wastewater, grey water, brackish groundwater) at the end-user level

Increase water use efficiency in services and industrial sectors

Promote rainwater harvesting from rooftops in urban areas

Reduce vandalism and encroachment on water resources and supply systems

Reduce groundwater over-abstraction to the limits of sustainable yield

Supply side management

Promote a proactive preventive approach (including, but not limited to, drinking water safety plans) to protect the country's limited water supplies

Improve drinking water quality management systems and surveillance programmes

Cap and regulate irrigated agriculture in the highlands and reinforce groundwater by-laws

Allocate resources in a balanced way, taking into consideration equity and social and economic returns from using water

Enhance surface water storage by using all available options, e.g. dams and reservoirs, ponds, and cisterns (water harvesting)

Enhance groundwater storage such as aquifer recharge and groundwater storage, and soil water storage

Improve water transfer systems between governorates and demand sites

Enhance wastewater collection and treatment services

Pursue the Red-Dead conveyance project and other sea water desalination projects with due consideration for the environmental and social sustainability of these projects

Promote desalination and the use of brackish groundwater for domestic and agricultural supply

Implement water resources quality protection to increase water availability for unrestricted use by updating and enforcing protection zones

Promote rainwater harvesting from rooftops in urban areas

Continue treated wastewater reuse in the Jordan Valley and Highlands to save freshwater based on the substitution principle

Promote grey water reuse in the municipal, industrial, and tourist sectors

Develop current groundwater resources and investigate alternatives

Integrated planning of domestic food production and imports: virtual water management

Integrated water and land planning, management, and zoning, and water-smart land use, including urban planning to stop encroachment and loss of agricultural land due to overgrazing, desertification, land degradation, erosion and reservoir sedimentation, implementing conservation agriculture and soil conservation to create improved soil water storage and soil filtering capacity, protecting groundwater recharge areas from pollution and promoting water-smart afforestation

Adopting a virtual water concept through imports of water-intensive products

International cooperation on water resource management

Improve international transboundary management of water resources as far as possible within the difficult political conditions in the region

Consider other Dead Sea policy options such as changing the regional water management practices so that freshwater from the Jordan and the Yarmouk river systems are diverted back to the Dead Sea

Develop proposals for drought adaptation in the water sector to incorporate financing from international climate change adaptation funds

Promote regional cooperation to preserve Jordan's water rights

Secure financing for no-regret measures in the water sector, with both national and international resources contributing to the goal

Integrated water information and database development

Improve climate, surface water and groundwater monitoring systems and data collection

Enhance access to water and climate data to enable early warning systems on drought and floods

Improve and update the water information systems based on improvements in data quality

Improve groundwater and surface water use data

Mainstream climate expertise into water management by facilitating the use of climate data for planning and early warning purposes (climate services)

Training, awareness, and capacity building

Encourage public awareness and behavioural change by working with existing networks such as the Highland Forums

Build political will to address climate change in water management

Raise public awareness about water saving, water-related issues, and water management

Train experts in the water sector to write successful proposals to access international climate funds 
Table 9 (continued)

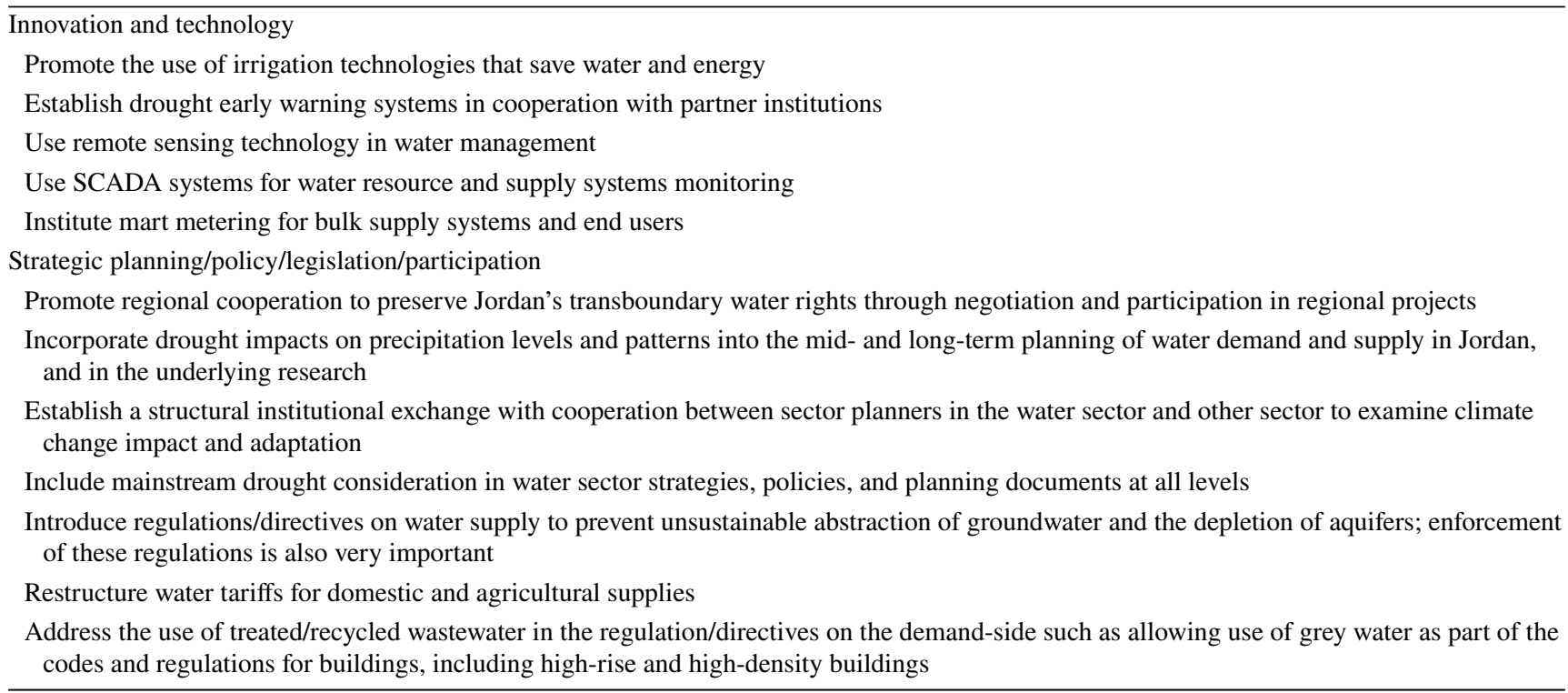

action plans and contingency plans to address various types of drought, and should encourage affected economic sectors and population groups to adopt self-reliance measures that enhance risk management.

Several groundwater management measures are proposed, including strategic planning, policy, legislation, public participation, water demand management, water supply side management, cooperation with neighbouring countries and the international community with regard to water resource management, integrated water information, database development, training, awareness and capacity building, and innovation and technology (Table 9). The reduction of groundwater abstraction by means of demand and supply water management plans should be included within the main implementation priorities. The demand and supply sides can be managed by developing non-conventional water supplies such as rainwater harvesting at all levels (desert, river dam, rooftops, etc.), wastewater treatment, desalinisation, grey water reuse, improving water saving through the adoption of more efficient irrigation technologies, and increased public awareness.

Drought in Jordan should be mainstreamed into strategies, policies, and planning documents at all levels. Although the current policies have main regulation to prevent unsustainable abstraction of groundwater and the depletion of aquifers, the urgent need for the enforcement of these regulations is also a must. Also, there should be a structural institutional exchange with cooperation between sector planners in the water sector and others sector to promote for drought management at all levels.

\section{Conclusions}

The drought impact chain framework and vulnerability mapping indicate that Jordan's groundwater systems are highly fragile and vulnerable to drought due to high exposure impacts, high sensitivity, and low or weak adaptive capacities. Drought in Jordan should thus be handled as an emergent crisis, and a well-established drought risk management system, including proactive plans and contingency plans, urgently needs to be developed and maintained by all ministries involved. However, this requires the adoption of enabling policies and legal frameworks at the national level to reduce drought impact. Management policies should be integrated to ensure sustainability of both water and the environment. Bearing in mind these challenges, the current means of coordination within the water sector and climate change/drought planning can be used to boost engagement in the water sector with regard to water resilience; however, fulfilling proper engagement for water planners requires taking the following points into account: (1) build willingness among decision-makers by recognising the importance of cooperation and collaboration; (2) strengthen the current means of communication and make all plans in coordination with the water sector representative on the national climate change committee; (3) ensure consistency between water sector policies and climate change/drought policies through encouraging the participation of each sector in the planning for the other sectors; (4) clarify accountability and follow-up and ensure transparency achieve objectives that depend 
on external factors; (5) ensure that climate change and drought planners continue to be aware of the importance of water manager participation in all activities, including capacity-building programmes.

Drought management should be mainstreamed into all of the country's developmental policies, plans, and programmes. Drought awareness should also be promoted amongst all levels of society, including facilitating the dissemination of environmental policies, strategies, acts, rules, regulations, and standards by print, audio-visual, and other appropriate means. Although this study suggests several drought management measures for the water sector, these drought adaptation plans should be institutionalised as an integral part of the development planning process. An efficient system of gathering, monitoring, and sharing drought information related to all impacted sectors must be promoted and supported, which can be achieved through coordination and facilitation of the implementation of bilateral and multilateral environmental agreements, conventions, treaties, or declarations.

Acknowledgements Open access funding provided by University of Szeged (SZTE).

Open Access This article is distributed under the terms of the Creative Commons Attribution 4.0 International License (http://creativeco mmons.org/licenses/by/4.0/), which permits unrestricted use, distribution, and reproduction in any medium, provided you give appropriate credit to the original author(s) and the source, provide a link to the Creative Commons license, and indicate if changes were made.

\section{References}

Abdulla F, Al Omari A (2008) Impact of climate change on the monthly runoff of a semi-arid catchment: case study Zarqa River Basin (Jordan). J App Biol Sci 2(1):43-50

Abdulla F, Eshtawi T (2015) Climate change effect on sediment yield at King Talal Dam (Jordan). Civil and Environ Res 7(7):13-26

Abu-Allaban M, El-Naqa A, Jaber M, Hammouri N (2015) Water scarcity impact of climate change in semi-arid regions: a case study in Mujib basin, Jordan. Arab J Geosci 8(2):951-959

Al Qatarneh G, Al-Smadi BA-ZK, Shatanawi KM (2018) Impact of climate change on water resources in Jordan: a case study of Azraq basin. Appl Water Sci 8(1):8-50

Aladaileh H, Al Qinna M, Karoly B, Al-Karablieh E, Rakonczai J (2019) An investigation into the spatial and temporal variability of the meteorological drought in Jordan. Climate 7(3):82

Al-Adamat R, Foster I, Baban S (2003) Groundwater vulnerability and risk mapping for the Basaltic aquifer of the Azraq basin of Jordan using GIS, Remote sensing and DRASTIC. Appl Geogr 23(4):303-324

Al-Bakri JT, Alnaimat MJ, Al-Karablieh E, Qaryouti EA (2019) Assessment of combined drought index and mapping of drought vulnerability in Jordan. Int J Eng Res Appl 9(3):59-68

Al-Karablieh E, Salman A (2016) Water resources, use and management in Jordan $-\mathrm{a}$ focus on groundwater. Project report No 11, groundwater governance in Arab World. International Water Management Institute (IWMI), Colombo

Al-Mashagbah A, Al-Farajat M (2013) Assessment of spatial and temporal variability of rainfall data using Kriging, Mann Kendall test and the Sen's slope estimates in Jordan from 1980 to 2007. Res J Environ Earth Sci 5(10):611-618

Al-Qinna MI, Hammouri NA, Obeidat MM, Ahmad FY (2011) Drought analysis in Jordan under current and future climates. Clim Change 106:421-440

Al-Shibli FM, Maher WA, Thompson RM (2017) The need for a quantitative analysis of risk and reliability for formulation of water budget in Jordan. J Earth Environ Sci 8(2):77-89

Al-Tabbal JA, Al-Zboon KK (2012) Suitability assessment of groundwater for irrigation and drinking purpose in the northern region of Jordan. J Environ Sci Technol 5(5):274-290

Arsenault C (2017) Climate change, refugees worsen Jordan's water woes. Thomson Reuters Foundation, London

Balint Z, Mutua FM, Muchiri P (2011) Drought monitoring with the combined drought Index. Methodology and Software, FAOSWALIM, Kenya

Balint Z, Mutua F, Muchiri P, Omuto CT, Ochieng OD (2013) Chapter 23-monitoring drought with the combined drought index in Kenya. In: Paron P, Omuto CT (eds) Kenya: a natural outlook. Geo-environmental resources and hazards. Elsevier, Netherlands

Bancheri M, Serafin F, Bottazzi M, Abera W, Formetta G, Rigon R (2018) The design, deployment and testing of Kriging models in GEO frame. Geosci Model Dev Discuss 11(6):2189-2207

Battikhi A (2013) Drought policy and food security in Jordan. HMNDP 13

DOS (2018) Jordan in Figures. Department of Statisitics, Jordan

El-Naqa A, Al-Shayeb A (2009) Groundwater protection and management strategy in Jordan. Water Resour Manage 23:2379-2394

El-Naser H (2014) Water security in the middle east. A crisis on top of a crisis. Stanford University, USA

GLOWA (2013) GLOWA Jordan River: an integrated approach to sustainable management of water resources under global change. Eberhard-Karls-University of Tübingeny, Tübingen

Goode DJ, Senior LA, Subah A, Ayman J (2013) Groundwater-level trends and forecasts, and salinity trends, in the Azraq, Dead Sea, Hammad, Jordan Side Valleys, Yarmouk, and Zarqa groundwater basins. US Geological Survey Open-File Report, Reston

Goovaerts P (1997) Geostatistics for natural resources evaluation. Oxford university press, Oxford

Goovaerts P (1999) Geostatistics in soil science: state-of-the-art and perspectives. Geoderma 89:1-45

Hajar HAA, Murad ZY, Shatanawi KM, Al-Smadi BM, Hajar YAA (2019) Drought assessment and monitoring in Jordan using the standardized precipitation index. Arabian J Geosci 12:417

Kogan FN (1990) Remote sensing of weather impacts on vegetation in non-homogeneous areas. Int J Remote Sens. 11(8):1405-1419. https://doi.org/10.1080/01431169008955102

Liamas MR, Custodio E (2003) Intensive use of groundwater: challenges and opportunities. Balkema Publishers, Lisse

Margane A, Hobler M, Droubi A, Rajab R, Subah A, Khater A (2004) Groundwater vulnerability mapping in the Arab region. In: Zereini F, Jaeschke W (eds) Groundwater in the middle east and north Africa-resources, protection and management. Springer, Berlin, p 115

MOA (2009) The Agricultural Risk Management Law No. 5 of 2009 and its amendments. Ministry of Agriculture, Jordan

MoEnv (2014) Jordan's third national communication on climate change. submitted to the united nations framework convention on climate change (UNFCCC), funded by GEF and UNDP. Ministry of Environment, Jordan

MoEnv (2016) Jordan's state of environment, second report. Ministry of Environment, Jordan 
Mohammad A, Almomani T, Alhejoj I (2015) Groundwater vulnerability for the surface outcropping aquifers in Jordan. J Environ Prot 6:250-258

Molle F, Al Karablieh E, Al Naber M, Closas A, Salman A (2017) Groundwater governance in Jordan the case of Azraq basin: a policy white paper. Groundwater governance in the Arab world. USAID, Washington

MWI (2016a) National water strategy 2016-2025: water sector policies. Ministry of Water and Irrigation, Jordan

MWI (2016b) National water strategy 2016-2025: groundwater sustainability policy. Ministry of Water and Irrigation, Jordan

MWI (2016c) National Water Strategy 2016-2025: Water Demand Management Policy. Ministry of Water and Irrigation, Jordan

MWI (2016d) Climate change policy for a resilient water sector. Ministry of Water and Irrigation, Jordan

MWI (2017) Jordan water sector facts and figures. Ministry of Water and Irrigation, Jordan

MWI (2018) Water sector policy for drought management. Ministry of Water and Irrigation, Jordan

MWI, "Water Sector in Jordan, Facts and Figures," Ministry of Water and Irrigation, Amman, Jordan, 2017

Nairizi S (2017) Irrigated agriculture development under drought and water scarcity

NCSCM (2015) Jordanian National Center for Security and Crisis Management. Jordanian National Center for Security and Crisis Management, Jordan

Rahman K, Gorelick SM, Dennedy-Frank PJ, Yoon J, Rajaratnam B (2015) Declining rainfall and regional variability changes in Jordan. Water Resour Res 51(5):3828-3835

Rajsekhar D, Gorelick SM (2017) Increasing drought in Jordan: climate change and cascading Syrian land-use impacts on reducing transboundary flow. Sci Adv 3(8):1-15
Salameh E, Bannayan H (1993) Water resources of Jordan. Present status and future potentials. Fridrich Ebert Stiftung, Jordan

Salman AZ, Al-Karablieh E (2004) Measuring the willingness of farmers to pay for groundwater in the highland areas of Jordan. Agric Water Manag 68(1):61-76

Salman A, Ibrahim KM, Saffarini G, Al-Qinna M (2009) Geostatistical calculation for clay reserve in Azraq Basin in Jordan. J Geogr Reg Plan 2(5):144-153

Selker JS, Keller CK, McCord JT (1999) Vadose zone processes. Lewis Publishers, Florida

Sivakumar M (2005) Impacts of natural disasters in agriculture, rangeland and forestry: an overview. In: Sivakumar MV (ed) Natural disasters and extreme events in agriculture, M. R. D. H. Springer, Berlin

SWALIM, "Drought Monitoring with Combined Drought Index; Methodology and Software.," Food and Agriculture organization of Untied Nations (FAO), 2011

Törnros T, Menzel L (2013) Characterizing droughts under current and future climates in the Jordan River region. Hydrol Earth Syst Sci Discuss 10(5):5875-5902

USAID (2018) Water management imitative: review of water scarcity ranking methodologies, vol 2018. USAID, Vermont

Wolff H-P, Al-Karablieh E, Al-Assa'd T, Subah A, Salman AZ (2012) Jordan water demand management study. Water Sci Technol 12(1):38-44

World Bank (2016) Promoting poverty reduction and shared prosperity: systematic country diagnostic; middle east and north Africa region. The World Bank Group, Washington 